\title{
Caracterização petrográfica e geoquímica da sequência magmática da Mina do Sei- val, Formação Hilário (Bacia do Camaquã - Neoproterozoico), Rio Grande do Sul, Brasil
}

\author{
Rodrigo W. LOPES ${ }^{1-2}$, Eduardo FONTANA ${ }^{1-2}$, André S. MEXIAS ${ }^{1}$, Márcia E.B. GOMES ${ }^{1}$, Lauro V.S. NARDI ${ }^{1}$ \& \\ Christophe RENAC ${ }^{2}$
}

1.Universidade Federal do Rio Grande do Sul. Av. Bento Gonçalves, 9500, CEP 91.540-000, Porto Alegre, RS, Brasil. E-mail: rodrigo.winck@ ufrgs.br,00068013@ufrgs.br, andre.mexias@ufrgs.br, marcia.boscato@ufrgs.br, lauro.nardi@ufrgs.br.

2.Université de Nice Sophia-Antipolis. Géoazur, 250 rue Albert Einstein, Sophia-Antipolis, 06560, Valbonne, França. E-mail: christophe. renac@unice.fr.

Recebido em 04/2013. Aceito para publicação em 02/2014.

Versão online publicada em 15/05/2014 (www.pesquisasemgeociencias.ufrgs.br)

\begin{abstract}
Resumo - A Mina do Seival é constituída por rochas vulcânicas e diques de composição andesítica e traqui-andesítica, dispostas em duas sequências. A sequência I inclui rochas piroclásticas e efusivas, e a sequência II é representada pelos diques de composição andesítica. Ambas são incluídas na Associação Shoshonítica de Lavras do Sul. Este magmatismo é relacionado ao estágio pós-colisional do ciclo Brasiliano/Pan-Africano, situando-se estratigraficamente no Alogrupo Bom Jardim, pertencendo à Formação Hilário na Bacia do Camaquã (Neoproterozoico). A área possui intensa alteração hidrotermal e mineralizações de $\mathrm{Cu}$. A mineralização e o magmatismo da Sequência II são controlados por estruturas tectônicas orientadas segundo N/NE e NO, que são relacionadas à distensão regional no período pós-colisional da Orogênese Brasiliano/Pan-Africana. Processos hidrotermais em diferentes temperaturas atuaram sobre estas rochas originando produtos de alteração pervasiva, principalmente clorita, corrensita e esmectita, com veios preenchidos por quartzo, carbonato, barita e minerais de cobre. Em ambas as sequências encaixantes da Mina do Seival é possível identificar a afinidade shoshonítica das rochas. Os elevados teores de $\mathrm{Cu}, \mathrm{Zn}$ e Ni nos diques em relação às rochas piroclásticas e às efusivas, mesmo nas mais hidrotermalizadas, sugerem que as principais ocorrências de mineralização de $\mathrm{Cu}$ têm origem magmática. Os dados químicos de rocha total indicam que o enriquecimento dos elementos componentes da mineralização, $\mathrm{Ag}, \mathrm{Au}, \mathrm{Cu}$ e Zn, está relacionado aos diques da Sequência II. Os teores de $\mathrm{Au}$ e Cu são mais elevados nas amostras com menores concentrações de carbonatos, sugerindo que a carbonatação não tem relação com a deposição dos minérios.
\end{abstract}

Palavras-chave: Mina do Seival, Alteração hidrotermal, Petrografia, Magmatismo Shoshonítico, Depósitos de Cobre, Geoquímica, Bacia do Camaquã.

\begin{abstract}
Petrographic and geochemical characterization of the magmatic sequence of Seival Mine, Hilario Formation (NEOPRoterozoic Camaquã Basin), Rio Grande do Sul, BraziL - The Seival Mine consists of andesitic volcanic and trachy-andesitic volcanic and hipabissal rocks grouped into two volcanic sequences. The Sequence I is composed of pyroclastic rocks and effusive rocks, and sequence II by andesite dikes. The area shows intense hydrothermal alteration and $\mathrm{Cu}$ mineralization. This magmatism is related to the post-collisional stage of the cycle Brasiliano/Pan-African, and it is stratigraphically positioned in the Bom Jardim Allogroup, Hilário Formation, which is part of the Neoproterozoic Camaquã Basin. Sequence II magmatism and mineralization are controlled by tectonic structures with N/NE and NW orientation, which are related to regional extension during the post-collisional stage of Brasiliano/Pan-African Orogeny. Processes involving different temperatures caused pervasive alteration products, with generation of chlorite, corrensite and smectite, with veins filled by quartz, carbonate, barite and copper minerals. In both sequences of Seival Mine is possible to identify the shoshonitic affinity of host sequences, as pointed out by geochemical data. The higher contents of $\mathrm{Cu}, \mathrm{Zn}$, and $\mathrm{Ni}$ in andesite dikes in relation to pyroclastic and effusive rocks, even in the hydrothermally altered types, suggest that the main $\mathrm{Cu}$ mineralizations have magmatic origin. The $\mathrm{Au}$ and $\mathrm{Cu}$ contents are higher in samples with lower carbonate concentrations, which suggests than carbonate alteration have no relation with ore deposition.
\end{abstract}

Keywords: Seival Mine, Hydrothermal alteration, Shoshonitic magmatism, Petrography, Copper deposits, Geochemistry, Camaquã Basin.

\section{Introdução}

O magmatismo da Bacia do Camaquã (BC) constitui uma das mais importantes manifestações geológicas do período pós-colisional na região sul do Brasil. 0 entendimento de suas fontes e de seus diferentes ciclos vulcânicos favorece a compreensão dos processos geradores dos principais depósitos de minério nessa região do Brasil.

Na região entre Caçapava do Sul e Lavras do Sul- 
-RS, a principal atividade econômica do início do século XX foi a mineração de $\mathrm{Au}, \mathrm{Cu}, \mathrm{Pb}, \mathrm{Zn}$. A Mina do Seival (MS) foi responsável por uma grande parte da produção de $\mathrm{Cu}$ no sul do Brasil. Esse minério foi lavrado de diversas formas, como minas, trincheiras e escavações. Sua gênese e posicionamento estratigráfico foram muito pouco investigados, sendo os estudos pretéritos de caráter descritivo. Atualmente a reserva encontra-se em exaustão econômica devido ao alto teor de $\mathrm{Cu}$ oxidado.

A evolução do sistema magmático que originou as rochas da MS foi responsável pelo empilhamento de sequências efusivas e piroclásticas e diques associados. Estas rochas são incluídas na Formação Hilário (FH) definida por Ribeiro \& Fantinel (1978) ou Aloformação Hilário senso Paim et al. (2000), inclusa no grupo Bom Jardim. A sequência efusiva e piroclástica é intrudida por diques de composição andesítica e provavelmente lamprofírica, de espessura métrica a decamétrica, de direção N-NE, resultantes dos estágios rúpteis de distensão regional. Na MS as rochas piroclásticas de fluxo e queda, e as efusivas foram classificadas como Sequência I e os diques de andesito como Sequência II. A FH em sua porção norte na região é constituída predominantemente por lavas andesíticas (Lima, 1995).

Os processos de alteração que atingem a grande parte das litologias da MS são favorecidas pela porosidade das rochas da sequência explosiva, bem como pela presença de fraturas e falhas. As mineralizações encontram-se alojadas principalmente em zonas rúpteis ao longo de direções N-NE e NW. O enriquecimento de $\mathrm{Cu}, \mathrm{Au}$ e $\mathrm{Ag}$ nos diques de andesito sugere que eles são os portadores dos elementos mineralizadores da área (Lopes, 2011). Os teores de $\mathrm{Cu}$ tendem a diminuir com o aumento da profundidade (Reischl, 1978), sendo mais um indicativo da ligação dos diques com as mineralizações na região.

0 presente estudo petrogenético contribui para a geração de um modelo evolutivo dos processos de alteração hidrotermal possibilitando o entendimento da geologia regional e das mineralizações da Bacia do Camaquã.

\section{Geologia Regional}

No estado do Rio Grande do Sul, o setor meridional da Província Mantiqueira (Almeida \& Hasui, 1984) recebe a denominação de Escudo Sul-rio-grandense (ESRG). Essa província se alonga do sul da Bahia até o Uruguai, e é resultado da orogenia que promoveu a colagem de terrenos neoproterozoicos, dando origem ao Paleocontinente Gondwana Ocidental. O ESRG foi compartimentado em termos tectônicos em quatro unidades (Fig. 1A), por Chemale Jr. (2000): 1) Bloco Taquarenbó, 2) Cinturão Vila Nova, 3) Tijucas e 4) Batólito Pelotas.

A região de Lavras do Sul é constituída por um embasamento de metaultramafitos, metagranitoides e xis- tos (Complexo Cambaí) que é parcialmente coberto por rochas sedimentares do Alogrupo Maricá, nas áreas de ocorrência da BC (Lima \& Nardi, 1998). Este conjunto foi posteriormente sobreposto e intrudido por rochas da Associação Shoshonítica de Lavras do Sul (ASLS), definida por Nardi \& Lima (1985). Granitoides e vulcanitos ácidos e básicos, de afinidade alcalina sódica saturada em sílica, e rochas sedimentares do Alogrupo Santa Bárbara sucedem esta associação (Fig. 1B).

\subsection{Geologia da Bacia do Camaquã}

No estágio pós-colisional do ESRG, desenvolveram-se extensas bacias vulcano-sedimentares, com muitos termos vulcânicos e vulcanoclásticos alcalinos sódicos e menos frequentes shoshoníticos, com idades neoproterozoicas. A evolução dessas bacias, constituintes do sistema Camaquã (Paim et al., 2000) está ligada a transcorrência dos terrenos e à sistemas deposicionais predominantemente continentais.

A BC é considerada uma bacia do tipo strike-slip (Lima et al., 2007) formada nos estágios pós-colisionais do ciclo orogênico Brasiliano/Pan-Africano, com vários episódios magmáticos com idade variando do Neoproterozoico ao Ordoviciano, intercalados com rochas sedimentares. Este ambiente geotectônico é resultado da colisão dos crátons de La Plata e Kalahari responsável pela formação do Supercontinente Gondwana em um período de pós-orogênese. No período pós-colisional, a transcorrência e rifteamento dos blocos foram responsáveis pelo magmatismo e formação da bacia, e explica o seu amplo intervalo de tempo 650?-470 Ma (Chemale Jr., 2000). O Sistema de Bacias Camaquã pode ser interpretado como um locus deposicional no qual ocorreu a superposição de diversos tipos de bacias que foram individualizadas em termos tectônicos, termomecânicos e geocronológicos, apresentando registros litológicos próprios e mecanismos de subsidência distintos (Paim et al., 2000). Em termos de evolução geológica, esta bacia foi caracterizada pela alternância de intervalos onde dominaram eventos deposicionais, com o acúmulo de espessos pacotes sedimentares e vulcano-sedimentares e intervalos dominantemente erosionais (Lima et al., 2007).

0 primeiro ciclo vulcânico, até agora reconhecido da $\mathrm{BC}$, é correlacionável à FH. Esse vulcanismo tem composição variando de basalto a riolito e afinidade shoshonítica (Lima \& Nardi, 1998). O segundo ciclo é incluído na Formação Acampamento Velho, de afinidade alcalina saturada em sílica ou moderadamente alcalina sódica (Wildner et al., 1999; Sommer et al. 2006, Matté et al., 2012), constituída predominantemente por vulcânicas de composição intermediária a ácida e rochas básicas. As rochas do Grupo Rodeio Velho dominantemente básicas de afinidade toleítica, representam o último ciclo vulcânico da BC, pertencentes ao Alogrupo Guaritas, associadas ao estágio de rifteamento da bacia (Lima et al., 2007). 
Na região da Mina Volta Grande, localizada a oeste da Mina do Seival, a caracterização geoquímica das lavas intermediárias e dos tufos de cristal associados, sugeriu condições subaéreas e a afinidade shoshonítica do vulcanismo (Lima, 1985). Nas proximidades de Caçapava do Sul, a nordeste da área estudada, as rochas da FH interdigitam-se e são gradacionalmente substi- tuídas volumetricamente por conglomerados aluviais ricos em clastos vulcânicos de composição básica a intermediária. Sua porção mais distal é composta por arenitos e siltitos relacionados a fluxos turbiditicos em porções subaquáticas de sistemas deltaicos (Paim et al., 2000).

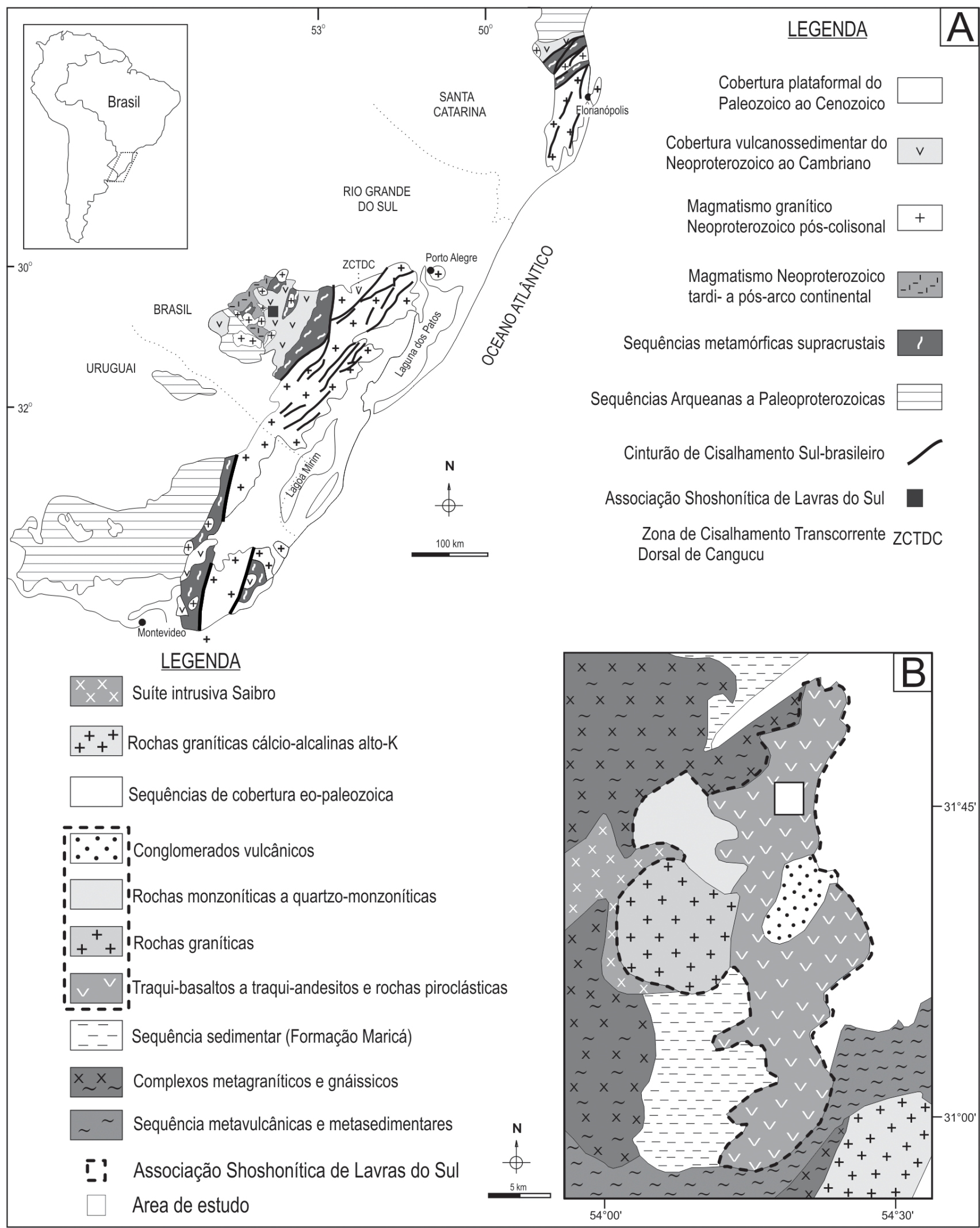

Figura 1. Mapa geológico do sul do Brasil, Uruguai e regional. A) Principais domínios geotectônicos do segmento meridional da Província Mantiqueira (modificado de Nardi \& Bitencourt, 2007); B) Mapa geológico da Associação Shoshonítica de Lavras do Sul e localização da área de estudo (modificado de Lima \& Nardi, 1998). 


\subsection{A Associação Shoshonítica de Lavras do Sul}

A ASLS de idade neoproterozoica apresenta características de um magmatismo pós-colisional relacionando aos estágios finais da Orogenia Brasiliana (Lima \& Nardi, 1998; Sommer et al., 2006; Liz et al., 2009a). Localizada no cinturão Vila Nova, possui na base traqui-basaltos potássicos, sucedidos por quatro ciclos efusivos shoshoníticos, além de depósitos piroclásticos de queda e fluxo (Lima, 1995). As rochas de composição andesítica da ASLS constituem a sequência denominada Formação Hilário (Ribeiro \& Fantinel, 1978) ou Aloformação Hilário (Paim et al., 2000), Grupo Bom Jardim (Fig. 2). A sudoeste da área da Mina do Seival ocorrem abundantes intrusões monzoníticas rasas, intrusões de diques traquiandesíticos à riolíticos e lamprófiros espessartíticos (Liz et al., 2009; Müller et al., 2012). A fase plutônica da ASLS é representada pelo núcleo do Complexo Granítico de Lavras do Sul (CGLS), definido por Nardi (1984).

As rochas vulcânicas são interestratificadas por uma sequência vulcanoclástica, incluindo tufos soldados. Esta sucessão é interpretada como produto de atividade vulcânica em ambiente subaéreo, possivelmente próximo a centros vulcânicos (Janikian et al., 2003). A presença de expressivos depósitos efusivos aliados a uma fração piroclástica de fluxo de composição variando de traquiandesítica a riolítica (Lima, 1995), especialmente na porção sudeste da CGLS, permite sugerir uma extração gradativa do magma responsável pela geração de um sistema de caldeira.
As intrusões monzoníticas rasas concentram-se principalmente na borda nordeste do CGLS, definindo um padrão geométrico semicircular, semelhante ao encontrado em terrenos vulcânicos associados a caldeiras, conforme sugerido por Lima (1995) e Gastal et al. (2008). As intrusões são posicionadas em condições epizonais, e incorporam grande quantidade de xenólitos do pacote de vulcanoclásticas basculadas durante o evento de subsidência de caldeira. Temporalmente vinculados aos monzonitos hipabissais ocorrem os diques riolíticos de espessuras decamétricas e as últimas manifestações efusivas intermediárias. Composições latíticas são representadas por diques decamétricos com direção NW-SE na porção nordeste de Lavras do Sul.

O núcleo do CGLS é constituído por granodioritos de afinidade shoshonítica, enquanto nas bordas do mesmo ocorrem granitos de afinidade alcalina sódica mais jovens. A região de exposição da ASLS, apresenta as camadas mergulhando para leste, assim explicando-se sua ausência na parte oeste da região, onde afloram intrusivas graníticas, conforme discutido por Mexias et al. (2007) e Bongiolo et al. (2011).

A sequência vulcânica foi datada por Janikian et al. (2008) pelo método $\mathrm{Ar}^{40} / \mathrm{Ar}^{39}$ em plagioclásios de piroclásticas que ocorrem a leste do CGLS, obtendo idade de $590 \pm 6 \mathrm{Ma}$, para o ciclo vulcânico da base, e $586 \pm 8$ Ma e $588 \pm 7$ Ma para a sequência efusiva superior. As rochas granodioríticas do núcleo do CGLS tem idade de 594 \pm 4 Ma (Remus et al., 2000), enquanto monzonitos mais jovens da mesma ASLS foram datados por Liz et

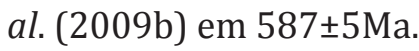

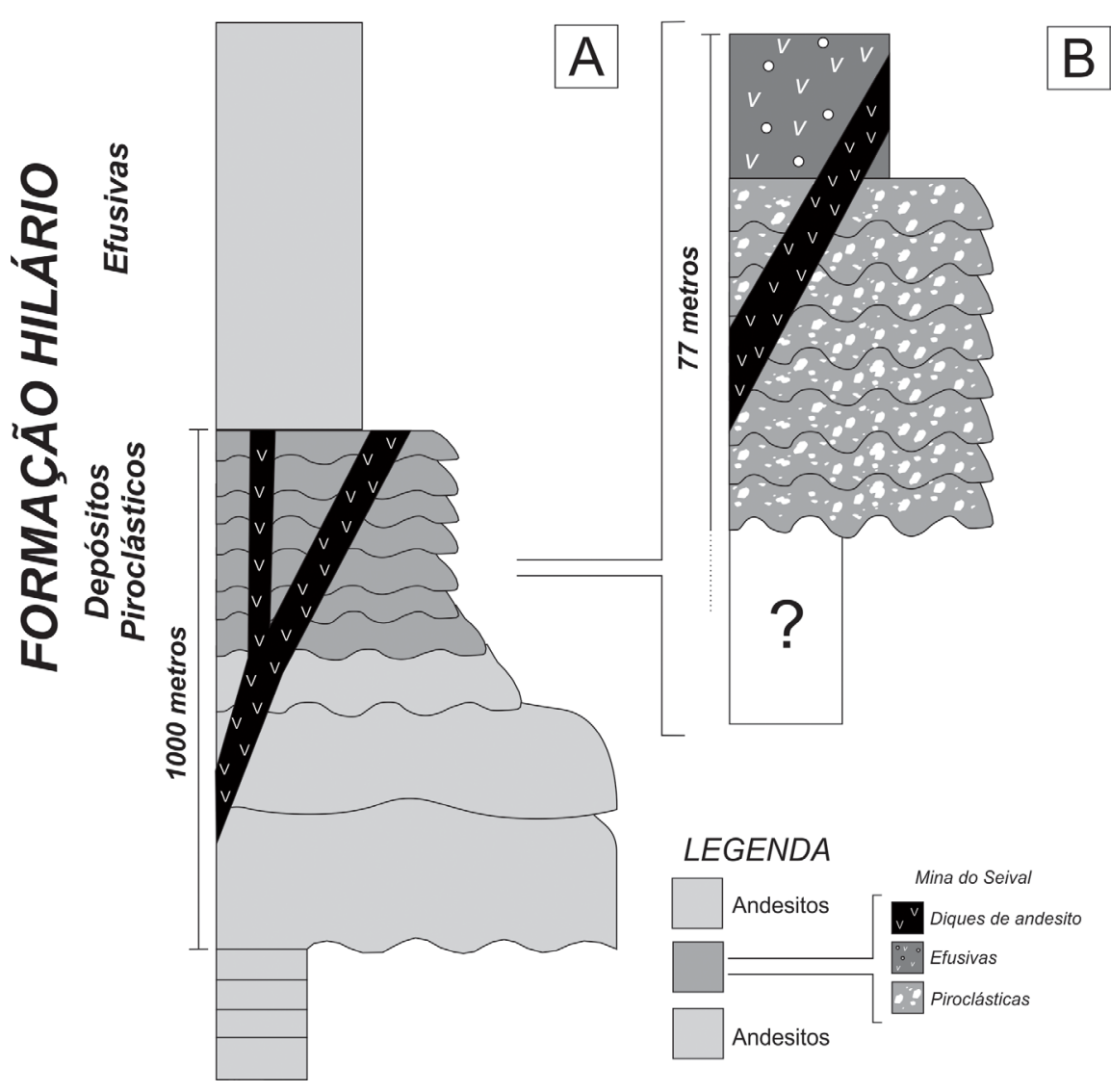

Figura 2. Coluna estratigráfica simplificada. A) Bacia do Camaquã, Formação Hilário (modificado de Janikian et al., 2008); B) representação esquemática do furo SV 7811 na Mina do Seival. 


\subsection{Geologia da Mina do Seival}

A área de estudo, denominada Mina do Seival, está situada a $324 \mathrm{~km}$ de Porto Alegre pela rodovia BR 290. A localidade está entre os limites municipais de Caçapava do Sul e Lavras do Sul, inserida na carta topográfica do Serviço Geológico do Exército, Folha Arroio América (SH.22-Y-A-IV-1, 1975), em escala de 1:50.000, entre as coordenadas planas (UTM) 6604000-6596000m N e $232000-236000 \mathrm{~m}$ E, sendo mapeada uma área com cerca de $30 \mathrm{Km}^{2}$ em escala 1:10.000.

A MS é composta por seis minas e pequenas ocorrências de cobre (Reischl, 1978) e possuem estruturação regional preferencialmente N-NE, e por vezes NW.
As minas são: (i) Alcides; (ii) ocorrência Vila do Torrão; (iii) Cruzeta, (iv) Meio; (v) Morcego; (vi) João Dahne; (vii) Barita (Fig. 3).

As rochas piroclásticas e efusivas fazem parte da Sequência I, enquanto os diques de andesito pertencem a Sequência II. A sequência I possui na base rochas piroclásticas, predominantes na área, e andesito amigdaloide no topo da sequencia I, sendo intrudidas pelos diques de andesito da sequencia II, pertencentes à FH. Na parte leste, sobrepostos a FH (Wildner et al., 2008) ocorrem conglomerados polimíticos e andesitos vesiculados possivelmente correlacionados à Formação Santa Bárbara.

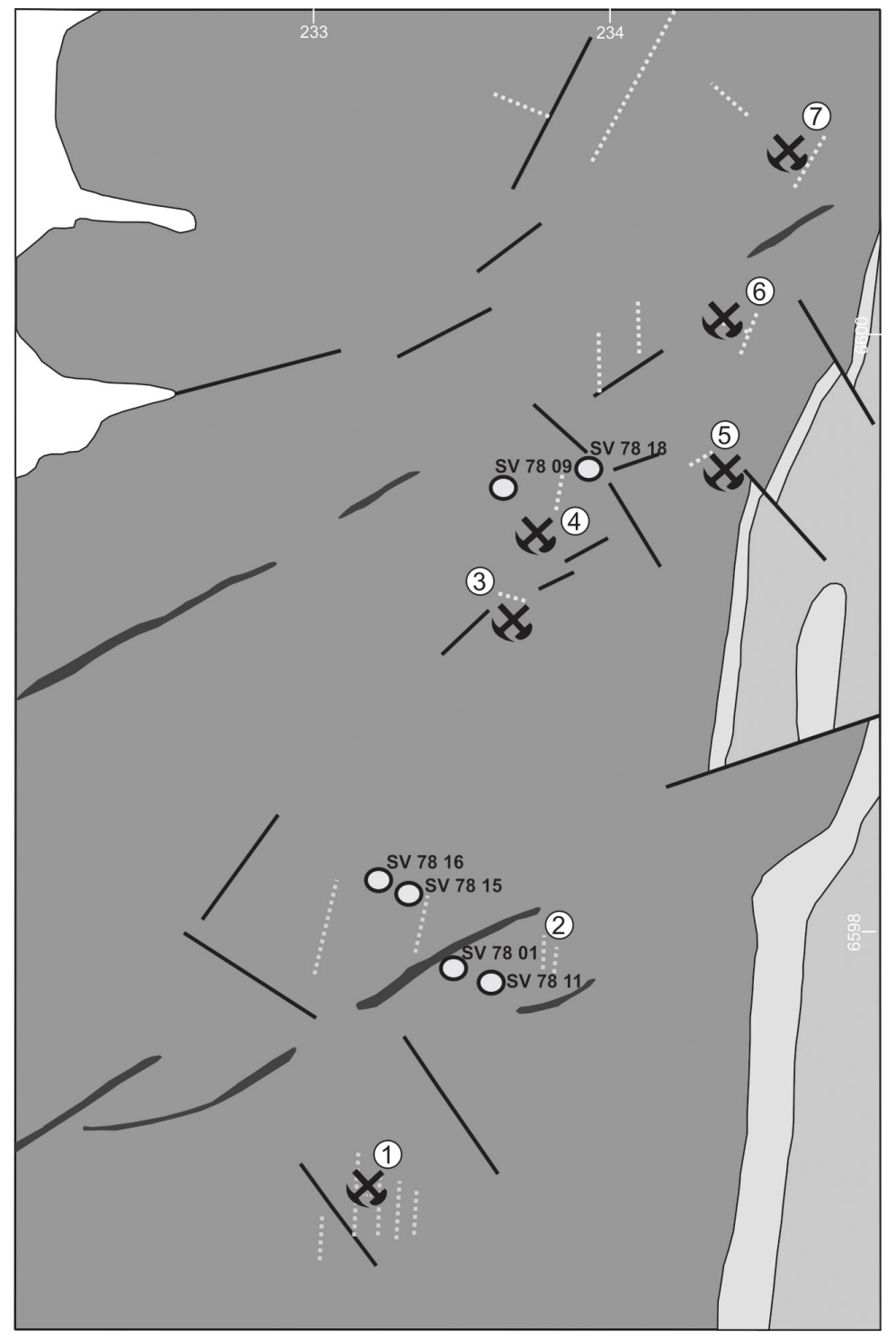
(1) Alcides
(2) Vila do Torrão
(3) Cruzeta
(4) Meio
(5) Morcego
(6) João Dahne
(7) Barita
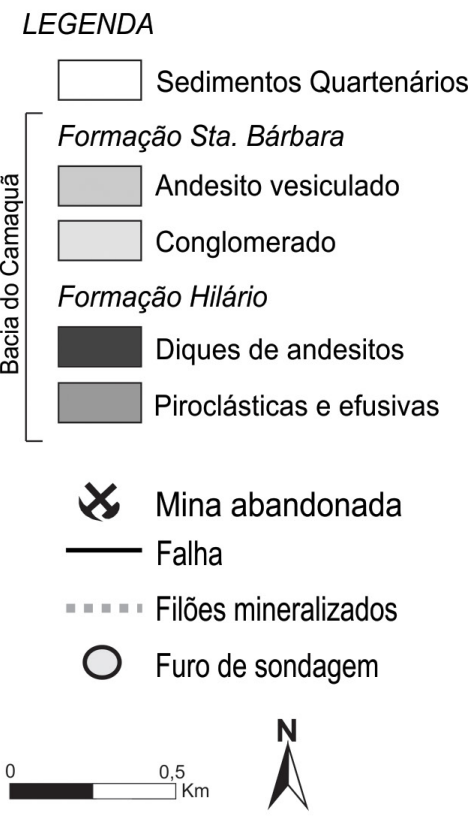

Figura 3. Mapa geológico e ocorrências na Mina do Seival (adaptado de Reischl, 1978; Lopes, 2011).

\section{Materiais e métodos}

A análise petrográfica foi realizada em amostras coletadas nos trabalhos de campo em superfície e de testemunhos de sondagem, através da análise das lâminas ao microscópio óptico e lupa binocular. As interpretações foram complementadas com o reconhe- cimento de alguns minerais com a difração de raios $\mathrm{X}$. A caracterização petrográfica envolveu a descrição de cerca de 50 lâminas delgadas. Foram descritos um total de 6 furos de sondagem da região da Mina do Seival: Linha 800: SV 78-11, SV 78-01; Linha 700: SV 78-15, SV 78-16; Linha 900: SV 78-18 e SV 78-09.

A difratometria de raios $\mathrm{X}$ (DRX) foi utilizada para 
análise mineralógica e determinação de espécies de argilominerais e seus politipos, em cada um dos ambientes selecionados a partir da petrografia.

0 equipamento utilizado é um difratômetro SIEMENS BRUKER AXS Modelo D5000 com goniômetro $\theta-\theta$. A radiação é K $\alpha$ em tubo de Cobre nas condições de $40 \mathrm{kV}$ e $25 \mathrm{~mA}$, no Laboratório de Difratometria de Raios X do CPGq/IG/UFRGS. A velocidade e o intervalo de varredura do goniômetro para cada tipo de análise são as seguintes: amostra em pó: 1 segundo para $0,02^{\circ}$ de degrau do goniômetro de $2^{\circ}$ a $72^{\circ} 2 \theta$; amostra orientada natural: 2 segundos para $0,02^{\circ}$ de degrau do goniômetro de $2^{\circ}$ a $28^{\circ} 2 \theta$; amostra orientada glicolada: 3 segundos para $0,02^{\circ}$ de degrau do goniômetro de $2^{\circ}$ a $28^{\circ} 2 \theta$; e para politipos: 5 segundos para $0,02^{\circ} \mathrm{de}$ degrau do goniômetro de $31^{\circ}$ a $53^{\circ} 2 \theta$.

Os minerais e/ou fases cristalinas são identificados através da medida das distâncias interplanares e das intensidades relativas dos picos nos difratogramas. Os minerais identificados, na análise total, apresentam-se comparados com padrões do banco de dados do computador (JCPDS) e indicado/referenciado sobre o pico mais importante e diagnóstico do mineral. As análises são interpretadas através do programa DIFFRAC PLUS onde os picos são indexados no difratograma.

As determinações de elementos maiores e traços foram realizados em 15 amostras representativas da MS, procurando abranger os diferentes tipos texturais e composicionais, com objetivo de classificar as rochas vulcânicas em relação às séries magmáticas e investigar sua evolução. As amostras foram preparadas no Anexo do Laboratório de Geologia Isotópica do IG/UFRGS e enviadas para análise de elementos maiores menores e traço no Activation Laboratories Ltd., Ontario, Canadá, através de fusion inductively coupled plasma emission spectrometry (FUSICP-ES) e fusion inductively coupled plasma mass spectrometry (FUS-ICP-MS) (Tab. 1).

\section{Resultados}

\subsection{Petrografia}

\section{Sequência I}

As rochas vulcânicas explosivas foram classificadas com base na granulometria (Fisher, 1966) em tufo-lapili e tufo-brecha (Fig. 4A). São compostos por clastos de diferentes composições (andesito porfirítico, andesito amigdalóide, andesito avermelhado, rochas piroclásticas) e possuem formas diversas, desde arredondadas a angulosas, geralmente com bordas curvilíneas. A matriz da rocha piroclástica é um tufo grosso $(0,05$ a $0,12 \mathrm{~mm})$ composto por cristaloclastos de plagioclásio, quartzo, matriz vítrea microcristalina e material opaco (Fig. 4B).

Os argilominerais predominantes são clorita (Fig. 5A), esmectita (Fig. 5B), corrensita (Fig. 5C) e ocorrem como produtos de alteração dos clastos, da matriz e também preenchendo cavidades. A clorita ocorre como produto de alteração da matriz da rocha, em veios preenchendo fraturas milimétricas e substituindo minerais como biotita. Associado à clorita ocorre epidoto (pistacita) na matriz da rocha e disseminado pelos clastos, com forma anédrica e intersticial. Os grãos de plagioclásio mostram intensa sericitização. A esmectita e corrensita foram determinadas com auxílio da DRX e ocorrem preferencialmente na matriz e substituindo os minerais máficos.

Os carbonatos são calcitas, caracterizados por DRX, e ocorrem principalmente nos veios $(0,1$ a 0,5 $\mathrm{cm}$ ) e na matriz das rochas e substituindo os minerais principais. São mais abundantes nas proximidades dos diques de andesito.

A alteração pervasiva transforma a grande maioria dos minerais máficos e subordinadamente os feldspatos que ocorrem na matriz e clastos. Os máficos, anfibólio e clinopiroxênio, mostram-se quase que totalmente substituídos por clorita, carbonato e hematita.

Os sulfetos são calcosina, pirita, calcopirita e bornita, frequentemente associados à malaquita. Localizam-se em zonas de fratura, onde se concentram as mineralizações, e também ocorrem de maneira disseminada a partir das fraturas ou como pequenos grãos dispersos na rocha. A barita ocorre preenchendo fraturas de espessuras centimétricas e sob a forma de cristais tabulares geminados, localmente alterados. Malaquita, azurita e hematita estão presentes como resultado do intenso intemperismo e ocorrem preferencialmente nas amostras de superfície. Ocorrência de quartzo euédrico em fraturas nas zonas de falha (Fig. 4C).

Os andesitos amigdaloides (Fig. 4D) possuem fenocristais de plagioclásio subédricos (0,1 a 0,5 mm), grãos arredondados de clinopiroxênio $(0,1 \mathrm{a} 0,5 \mathrm{~mm})$ e pseudomorfos de anfibólios. A matriz possui plagioclásios orientados definindo uma textura traquítica e os pseudomorfos de anfibólios ocorrem com maior frequência em relação às rochas piroclásticas. As amígdalas tem cerca de 0,5 a $1,0 \mathrm{~mm}$ e aparentam orientação por fluxo (Fig. 4E), e por vezes coalescência, com formas achatadas a arredondadas. São preenchidas por clorita-calcita, clorita-esmectita, clorita-esmectita-calcita (Fig. 4F) ou clorita-quartzo.

A rocha mostra intensa alteração hidrotermal e a clorita ocorre substituindo minerais primários, a matriz microcristalina, ou na borda de amígdalas e cavidades. A malaquita e hematita estão presentes como produtos supergênicos.

Na Mina João Dahne, no NE da área, ocorre uma vulcânica lamprofírica (espessartito) com fenocristais de clinopiroxênio euédricos a subédricos $(0,5 \mathrm{~cm})$, anfibólio subédrico $(0,4 \mathrm{~mm})$ e raro plagioclásio $(0,2 \mathrm{~mm})$ com corrosão na parte interna. A matriz é composta por microfenocristais de plagioclásio orientados, piroxênio e anfibólio, com alteração na forma de carbonato e clorita. 
Tabela 1. Teores de elementos maiores, menores e traço das rochas da sequência vulcânica Mina do Seival.

\begin{tabular}{|c|c|c|c|c|c|c|c|c|c|c|c|c|c|c|c|}
\hline Amostras & RFM 22 & RFM 18 & RFM 62 & RFM 48 & RFM 89 & RFM 83 & RFM 38 & RFM 32 & RFM 60 & FM 12 & FM 13 & FM 14 & RFM 44 & RFM 51 & RFM 66 \\
\hline $\mathrm{SiO2}$ & 54,67 & 55,58 & 52,41 & 48,8 & 49,74 & 62,82 & 53,6 & 53,25 & 54,79 & 56,21 & 55,63 & 55,45 & 56,45 & 56,6 & 54,7 \\
\hline Ti02 & 0,61 & 0,63 & 0,7 & 0,77 & 0,72 & 0,59 & 0,64 & 0,81 & 0,9 & 0,95 & 0,91 & 0,94 & 1,03 & 1 & 0,73 \\
\hline Al203 & 12,51 & 12 & 13,77 & 13,7 & 14,27 & 13,49 & 13,59 & 12,61 & 18,83 & 18,01 & 18,04 & 18,22 & 16,03 & 15,12 & 20,05 \\
\hline Fe203T & 6,5 & 6,89 & 7,13 & 7,61 & 6,2 & 7,32 & 6,33 & 7,03 & 6,38 & 5,79 & 5,42 & 5,69 & 6,28 & 6,28 & 6,73 \\
\hline Mno & 0,07 & 0,07 & 0,15 & 0,12 & 0,12 & 0,08 & 0,14 & 0,32 & 0,07 & 0,09 & 0,09 & 0,1 & 0,12 & 0,12 & 0,08 \\
\hline MgO & 7,9 & 7,74 & 3,52 & 4,4 & 2,82 & 2,77 & 2,94 & 4,67 & 2,25 & 4,44 & 4,71 & 4,59 & 2,2 & 2,6 & 1,5 \\
\hline $\mathrm{CaO}$ & 5,39 & 5,42 & 7,91 & 8,44 & 10,52 & 1,57 & 7 & 6,78 & 6,85 & 2,08 & 2,04 & 2,14 & 4,62 & 4,51 & 5,08 \\
\hline $\mathrm{Na} 20$ & 3,21 & 2,78 & 4,03 & 4,54 & 2,91 & 3,26 & 4,69 & 3,99 & 3,9 & 7,06 & 6,92 & 7,06 & 4,4 & 4,76 & 4,39 \\
\hline K2O & 1,86 & 1,61 & 1,67 & 0,96 & 2,05 & 3,78 & 3,05 & 2,47 & 2,48 & 1,58 & 1,61 & 1,47 & 3,76 & 3,42 & 2,75 \\
\hline P205 & 0,25 & 0,25 & 0,27 & 0,28 & 0,27 & 0,25 & 0,25 & 0,32 & 0,37 & 0,47 & 0,44 & 0,46 & 0,48 & 0,45 & 0,31 \\
\hline LOI & 6,6 & 6,6 & 8,1 & 10,1 & 10 & 3,8 & 7,3 & 7,5 & 2,8 & 3 & 3,9 & 3,6 & 4,2 & 4,8 & 3,3 \\
\hline Tot & 99,57 & 99,57 & 99,66 & 99,72 & 99,62 & 99,73 & 99,53 & 99,75 & 99,62 & 99,68 & 99,71 & 99,72 & 99,57 & 99,66 & 99,62 \\
\hline Ba & 797 & 684 & 844 & 272 & 880 & 842 & 803 & 1082 & 1225 & 394 & 411 & 506 & 1156 & 1019 & 1832 \\
\hline $\mathbf{R b}$ & 32,3 & 28,8 & 30,6 & 15,3 & 46,3 & 108,3 & 61,6 & 49,5 & 60,9 & 35,6 & 39,4 & 38,8 & 124,1 & 86,5 & 38,6 \\
\hline $\mathrm{Sr}$ & 753,5 & 722,9 & 535,4 & 253,3 & 774,9 & 273 & 298 & 226,2 & 1353,7 & 428,1 & 499 & 551,5 & 765,4 & 231,4 & 1215,4 \\
\hline $\mathbf{Y}$ & 11,2 & 10,8 & 13,7 & 13,8 & 12 & 10 & 11,8 & 17,6 & 16,7 & 15,2 & 16,3 & 15,2 & 18,9 & 21,7 & 14,9 \\
\hline $\mathrm{Zr}$ & 125,8 & 124,7 & 137,4 & 139,3 & 155,6 & 145 & 143,4 & 149,8 & 168,9 & 190,1 & 189,6 & 194,5 & 460,6 & 431 & 187,4 \\
\hline $\mathbf{N b}$ & 7,4 & 7,3 & 7,9 & 8,6 & 8,7 & 8,8 & 7,6 & 7,9 & 9,3 & 10,8 & 10,8 & 11,5 & 26,5 & 24,9 & 10,3 \\
\hline Th & 5,5 & 5,2 & 5,9 & 5,8 & 7 & 7,4 & 6,1 & 8,4 & 10,2 & 12,3 & 11,5 & 12,6 & 28,6 & 27,7 & 11,3 \\
\hline $\mathbf{P b}$ & 10,4 & 11,7 & 7,7 & 3,8 & 14,3 & 5 & 6,2 & 10,6 & 9,1 & 3,7 & 2,8 & 2,6 & 25,9 & 6,3 & 4,7 \\
\hline Ga & 17,2 & 16,7 & 18,1 & 16,7 & 18,8 & 19,1 & 16,4 & 17,3 & 25 & 21,8 & 23 & 22,4 & 26,3 & 22,7 & 25,4 \\
\hline $\mathrm{Zn}$ & 60 & 61 & 62 & 38 & 35 & 72 & 62 & 76 & 62 & 231 & 141 & 77 & 75 & 82 & 71 \\
\hline $\mathrm{Cu}$ & 33,9 & 28,4 & 27,1 & 52,1 & 22,9 & 72,5 & 1355,7 & 55,2 & 86,8 & 317 & 363,5 & 242,3 & 80,2 & 138,7 & 65,6 \\
\hline $\mathbf{N i}$ & 175,2 & 201,2 & 158,1 & 145,7 & 175,7 & 183,2 & 115,8 & 17 & 11,2 & 8,6 & 10,3 & 7,1 & 70,1 & 56,8 & 4,1 \\
\hline $\mathbf{V}$ & 100 & 99 & 108 & 117 & 109 & 102 & 87 & 143 & 124 & 112 & 104 & 111 & 72 & 69 & 61 \\
\hline Hf & 3,4 & 3,3 & 3,6 & 3,3 & 3,9 & 3,9 & 3,7 & 4,3 & 4,1 & 4,9 & 4,6 & 4,6 & 10,2 & 9,7 & 5,1 \\
\hline Cs & 1 & 1,1 & 1,8 & 0,7 & 3,4 & 2,4 & 0,7 & 0,9 & 1,7 & 3,1 & 3 & 3,4 & 3,5 & 2,4 & 2,8 \\
\hline Sc & 14 & 15 & 16 & 17 & 15 & 13 & 13 & 18 & 12 & 11 & 10 & 11 & 8 & 9 & 8 \\
\hline $\mathrm{Ta}$ & 0,4 & 0,4 & 0,4 & 0,4 & 0,5 & 0,5 & 0,4 & 0,4 & 0,5 & 0,6 & 0,6 & 0,6 & 1,3 & 1,1 & 0,5 \\
\hline Co & 32 & 30,7 & 26,2 & 32,7 & 30,2 & 28,5 & 27,3 & 19,5 & 15,1 & 13,9 & 13,4 & 13 & 18,3 & 13,7 & 10,1 \\
\hline $\mathrm{Be}$ & $<1$ & 1 & 2 & 2 & 2 & 2 & $<1$ & 4 & 2 & $<1$ & 1 & 3 & 4 & 4 & 3 \\
\hline $\mathbf{U}$ & 2,2 & 2,1 & 2 & 3,2 & 2,6 & 2,3 & 2 & 2,9 & 3,7 & 4,5 & 4,3 & 4,7 & 10,5 & 8,6 & 3,9 \\
\hline w & $<0,5$ & 1,1 & 0,5 & 5,3 & 1 & 0,8 & 0,8 & 0,8 & 1,1 & 0,9 & 0,7 & 1,1 & 2,2 & 2,6 & 1,9 \\
\hline Sn & 1 & 1 & 1 & 2 & 2 & 2 & 1 & 1 & 2 & 2 & 2 & 2 & 4 & 4 & 2 \\
\hline Mo & 0,6 & 0,5 & 0,3 & 0,2 & 0,4 & 0,5 & 0,7 & 0,8 & 0,5 & 0,9 & 0,4 & 0,7 & 0,7 & 0,8 & 0,6 \\
\hline $\mathrm{Au}$ & 1,5 & $<0,5$ & 1,8 & 1,5 & 0,8 & 0,8 & 1,9 & 4,1 & 5,5 & 7,2 & 4,4 & 3,6 & 2,5 & 2,1 & 2,7 \\
\hline La & 31,5 & 30,7 & 31,4 & 35,4 & 34,6 & 38,2 & 31,5 & 38 & 42,5 & 46,2 & 42,2 & 54,9 & 85,2 & 86 & 44,3 \\
\hline Ce & 61,2 & 59,5 & 64,9 & 72,8 & 68,7 & 68,3 & 63 & 77,2 & 82,3 & 97,1 & 93,7 & 105,7 & 167,2 & 161,6 & 87 \\
\hline Pr & 7,14 & 6,87 & 7,6 & 8,37 & 7,84 & 7,67 & 7,07 & 9,2 & 9,75 & 11,11 & 11,07 & 11,86 & 17,94 & 17,76 & 10,16 \\
\hline Nd & 27,8 & 26,8 & 29,7 & 34,6 & 29,6 & 27,9 & 25,3 & 35,3 & 37,5 & 42 & 42,6 & 45,1 & 62,1 & 61,3 & 40,1 \\
\hline Sm & 4,73 & 4,82 & 5,43 & 6,07 & 5,24 & 4,61 & 4,57 & 6,59 & 6,76 & 7,25 & 7,39 & 7,56 & 9,45 & 9,43 & 7,18 \\
\hline Eu & 1,22 & 1,23 & 1,56 & 1,59 & 1,38 & 1,13 & 1,18 & 1,6 & 1,84 & 1,79 & 1,96 & 1,99 & 1,79 & 1,68 & 1,79 \\
\hline Gd & 3,39 & 3,43 & 3,95 & 4,29 & 3,69 & 3,21 & 3,14 & 4,87 & 4,98 & 4,98 & 5,2 & 5,18 & 5,9 & 6,21 & 4,86 \\
\hline $\mathbf{T b}$ & 0,45 & 0,47 & 0,53 & 0,52 & 0,51 & 0,41 & 0,45 & 0,68 & 0,69 & 0,7 & 0,7 & 0,68 & 0,8 & 0,84 & 0,63 \\
\hline Dy & 2,1 & 2,11 & 2,77 & 2,86 & 2,38 & 2,02 & 2,14 & 3,1 & 3,15 & 3,27 & 3,27 & 3,27 & 3,66 & 3,72 & 2,92 \\
\hline Но & 0,43 & 0,41 & 0,51 & 0,45 & 0,46 & 0,29 & 0,39 & 0,65 & 0,62 & 0,56 & 0,58 & 0,52 & 0,65 & 0,69 & 0,52 \\
\hline Er & 1,22 & 1,11 & 1,43 & 1,23 & 1,22 & 0,96 & 1,11 & 1,74 & 1,58 & 1,54 & 1,48 & 1,59 & 1,72 & 1,97 & 1,47 \\
\hline $\mathrm{Tm}$ & 0,16 & 0,17 & 0,19 & 0,18 & 0,18 & 0,13 & 0,16 & 0,24 & 0,23 & 0,24 & 0,22 & 0,23 & 0,28 & 0,28 & 0,21 \\
\hline $\mathrm{Yb}$ & 1,11 & 0,97 & 1,2 & 1,26 & 1,06 & 0,99 & 1,03 & 1,46 & 1,47 & 1,45 & 1,41 & 1,3 & 1,67 & 1,9 & 1,57 \\
\hline Lu & 0,16 & 0,16 & 0,18 & 0,18 & 0,19 & 0,14 & 0,16 & 0,24 & 0,21 & 0,2 & 0,2 & 0,19 & 0,27 & 0,27 & 0,21 \\
\hline Cr203 & 0,066 & 0,076 & 0,071 & 0,082 & 0,081 & 0,07 & 0,046 & $<0,002$ & 0,006 & 0,003 & 0,003 & 0,004 & 0,018 & 0,016 & $<0,002$ \\
\hline $\mathbf{B i}$ & 0,2 & 0,2 & $<0,1$ & $<0,1$ & $<0,1$ & $<0,1$ & $<0,1$ & $<0,1$ & 0,1 & $<0,1$ & $<0,1$ & $<0,1$ & 0,1 & $<0,1$ & 0,1 \\
\hline Cd & $<0,1$ & $<0,1$ & $<0,1$ & $<0,1$ & $<0,1$ & $<0,1$ & $<0,1$ & $<0,1$ & $<0,1$ & $<0,1$ & $<0,1$ & $<0,1$ & $<0,1$ & $<0,1$ & $<0,1$ \\
\hline $\mathrm{Hg}$ & 0,11 & 0,33 & $<0,01$ & 0,03 & $<0,01$ & 0,05 & 0,1 & $<0,01$ & $<0,01$ & 0,28 & 0,2 & 0,18 & 0,11 & 0,07 & 0,09 \\
\hline Sb & 0,1 & $<0,1$ & $<0,1$ & $<0,1$ & 0,1 & 0,3 & 0,2 & 0,2 & 0,8 & 0,2 & $<0,1$ & $<0,1$ & & 0,1 & 0,1 \\
\hline Se & $<0,5$ & 1 & $<0,5$ & $<0,5$ & $<0,5$ & $<0,5$ & $<0,5$ & $<0,5$ & $<0,5$ & $<0,5$ & $<0,5$ & $<0,5$ & 0,3 & $<0,5$ & $<0,5$ \\
\hline Tl & $<0,1$ & 0,2 & $<0,1$ & $<0,1$ & $<0,1$ & $<0,1$ & $<0,1$ & $<0,1$ & $<0,1$ & $<0,1$ & $<0,1$ & $<0,1$ & $<0,5$ & $<0,1$ & $<0,1$ \\
\hline $\mathrm{Ag}$ & $<0,1$ & $<0,1$ & $<0,1$ & $<0,1$ & $<0,1$ & $<0,1$ & 2,4 & $<0,1$ & $<0,1$ & 0,5 & 0,5 & 0,3 & $<0,1$ & 0,4 & $<0,1$ \\
\hline As & 4,2 & 19,8 & 4,7 & 2,8 & 5,2 & 5,2 & 13,8 & 8,2 & 26,9 & 5,6 & 4,1 & 2,9 & 11,2 & 5 & 19,4 \\
\hline TOT/C \% & 0,11 & 0,17 & 1,44 & 1,75 & 2,06 & 0,22 & 1,4 & 1,15 & 0,07 & 0,06 & 0,06 & 0,05 & 0,53 & 0,74 & 0,17 \\
\hline TOT/S \% & $<0,02$ & 0,07 & $<0,02$ & $<0,02$ & $<0,02$ & $<0,02$ & $<0,02$ & $<0,02$ & $<0,02$ & $<0,02$ & $<0,02$ & $<0,02$ & $<0,02$ & $<0,02$ & $<0,02$ \\
\hline
\end{tabular}



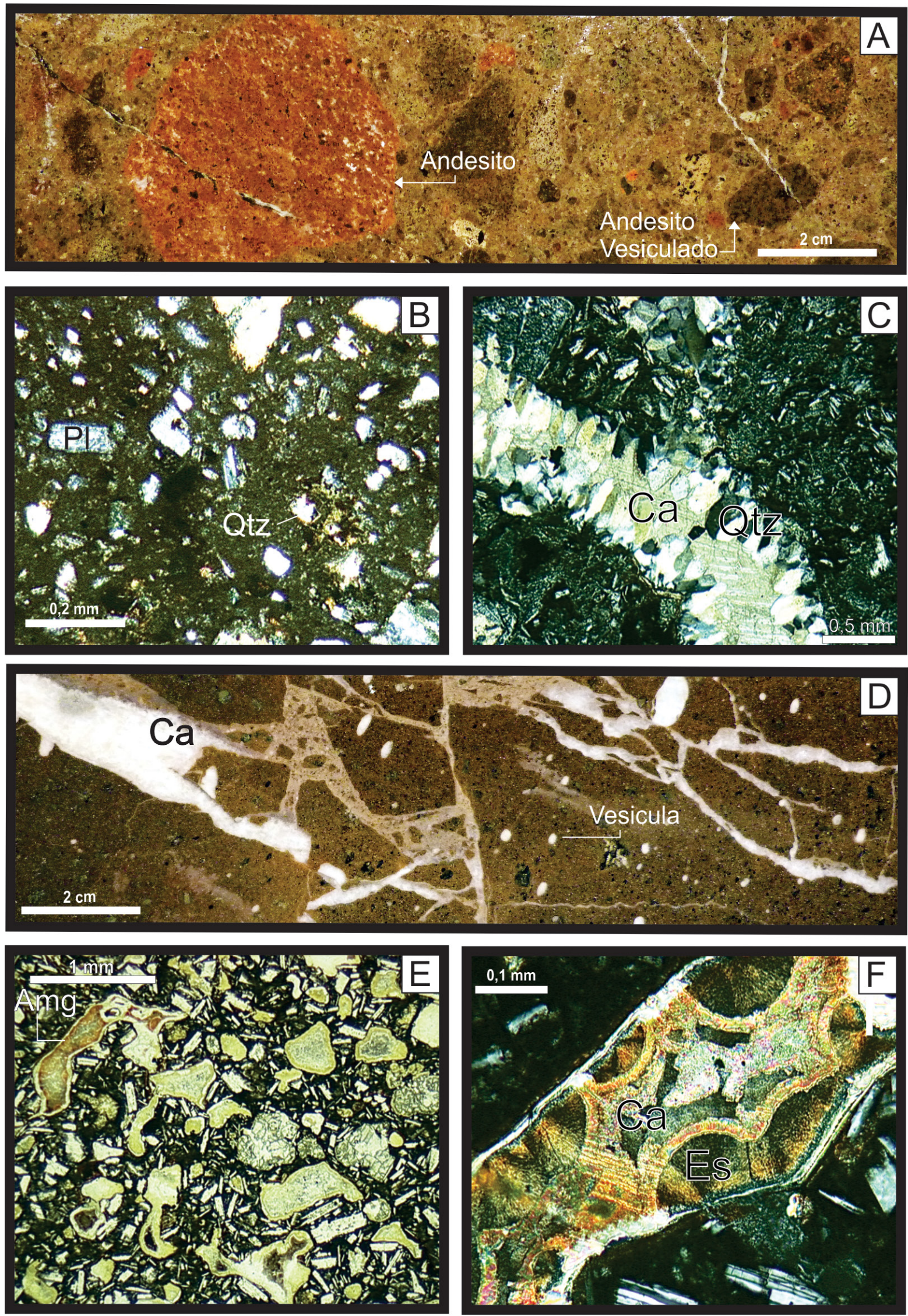

Figura 4. Fotos de amostras representativas da Sequência I na Mina do Seival. A) lapili-tufo com variação na composição dos clastos; B) andesito vesiculado do topo da sequência vulcânica; C) tufo grosso como matriz de rocha piroclástica; D) piroclástica com veio de quartzo euédrico preenchido por carbonato e sulteto; E) clasto de andesito amigdalóide; F) amígdala de clasto do andestido amigdaloide preenchida por esmectita e calcita. Ca: calcita; Pl: plagioclásio; Qtz: quartzo; Amg: amígdala; Es: esmectita. 

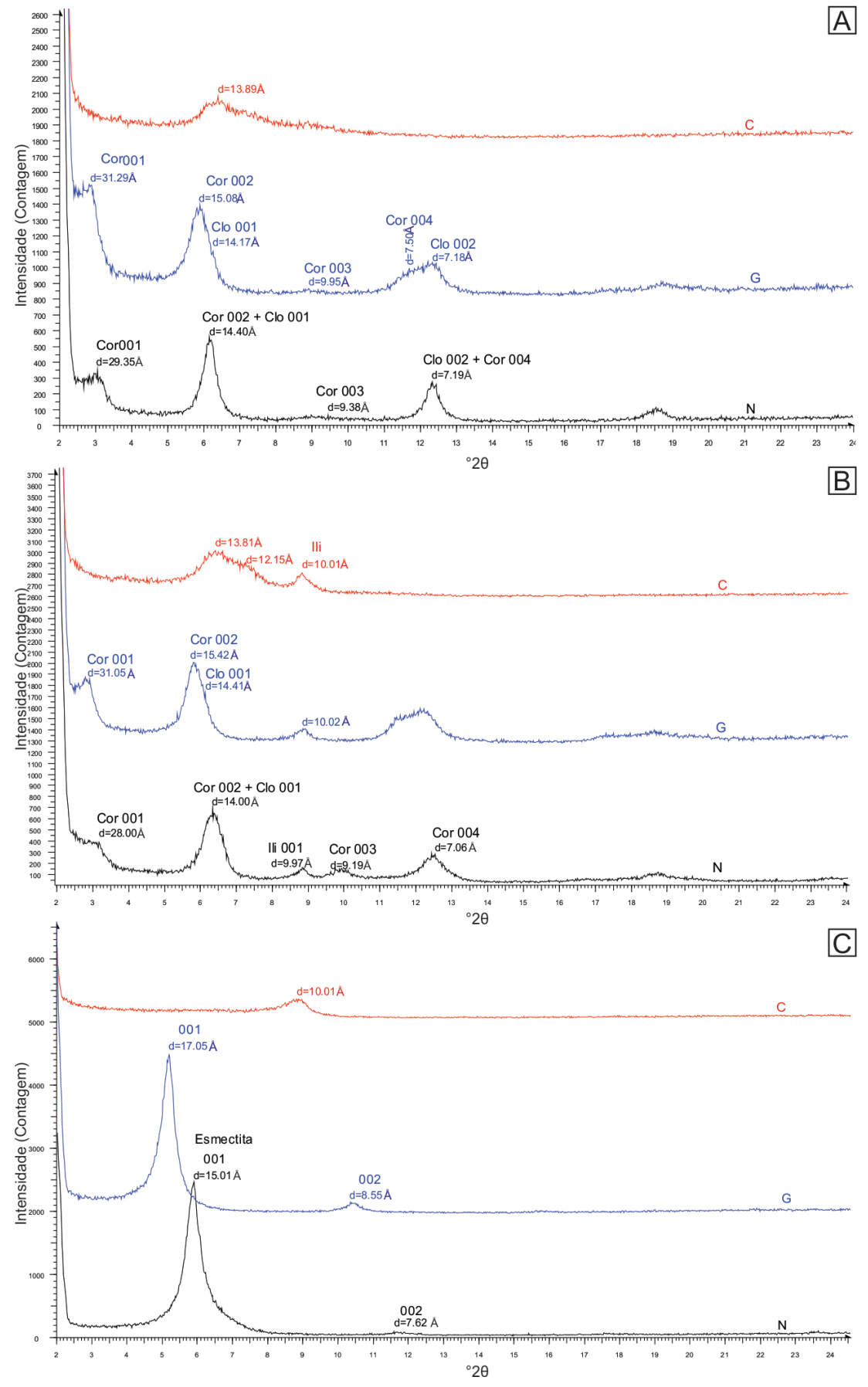

Figura 5. Difratometria de raios X de amostras orientadas fração $<2 \mu \mathrm{m}$, para rochas piroclásticas na Mina do Seival. A) Clorita e corrensita; B) Clorita, corrensita e ilita; C) Esmectita. Cl: clorita, Cor: corrensita, Ili: ilita, N: natural seca ao ar, G: glicolada, C: calcinada e aquecida a $550^{\circ} \mathrm{C}$ por $2 \mathrm{~h}$.

\section{Sequência II}

Os diques da sequência II da região da MS preenchem um sistema de falhas e fraturas associadas da evolução tectônica rúptil da evolução da BC. Os diques podem ser observados em superfície onde são encontrados na forma de corpos alongados de espessura métrica a decamétrica, bem como nos furos de sondagem da linha P800 em profundidades que variam de 30 a 40 m (Fig. 6A). No contato com o material piroclástico, os diques exibem orientação dos plagioclásios, e intensa alteração da matriz (Fig. 6B).

$\mathrm{O}$ andesito com textura traquítica possui fenocristais abundantes de plagioclásio subédrico a euédrico com dimensões entre $0,2 \mathrm{~mm}$ e $6,0 \mathrm{~mm}$ com intensa sericitização. Os plagioclásios geralmente possuem bordas e planos de maclas corroídas (Fig. 6C). Pseudomorfos de piroxênio com dimensões médias de 3,0 mm são geralmente substituídos por clorita e calcita, e estão dispersos em matriz fanerítica muito fina a afanítica microcristalina composta por micrólitos de plagioclásios orientados e piroxênios. Associado à clorita, ocorre epidoto secundário tanto substituindo fenocristais e como na matriz. Além de clorita, a corrensita é um dos minerais de alteração hidrotermal identificados na DRX, substituindo minerais máficos de maneira pervasiva na rocha. 
Próximo à ocorrência Vila do Torrão ocorre um biotita-andesito, com fenocristais de plagioclásio e biotita lamelar numa matriz oxidada, com intensa alteração de hematita composta por plagioclásio, quartzo, K-feldspato e hematita secundária (Fig. 6D). Associados à biotita, observa-se cristais euédricos de apatitas e amorfos de óxido de ferro. 0 piroxênio e anfibólio são parcial ou totalmente substituídos por argilominerais.

A biotita está alterada para clorita e óxido de ferro. A intensa cloritização e carbonatação na matriz ocasio-
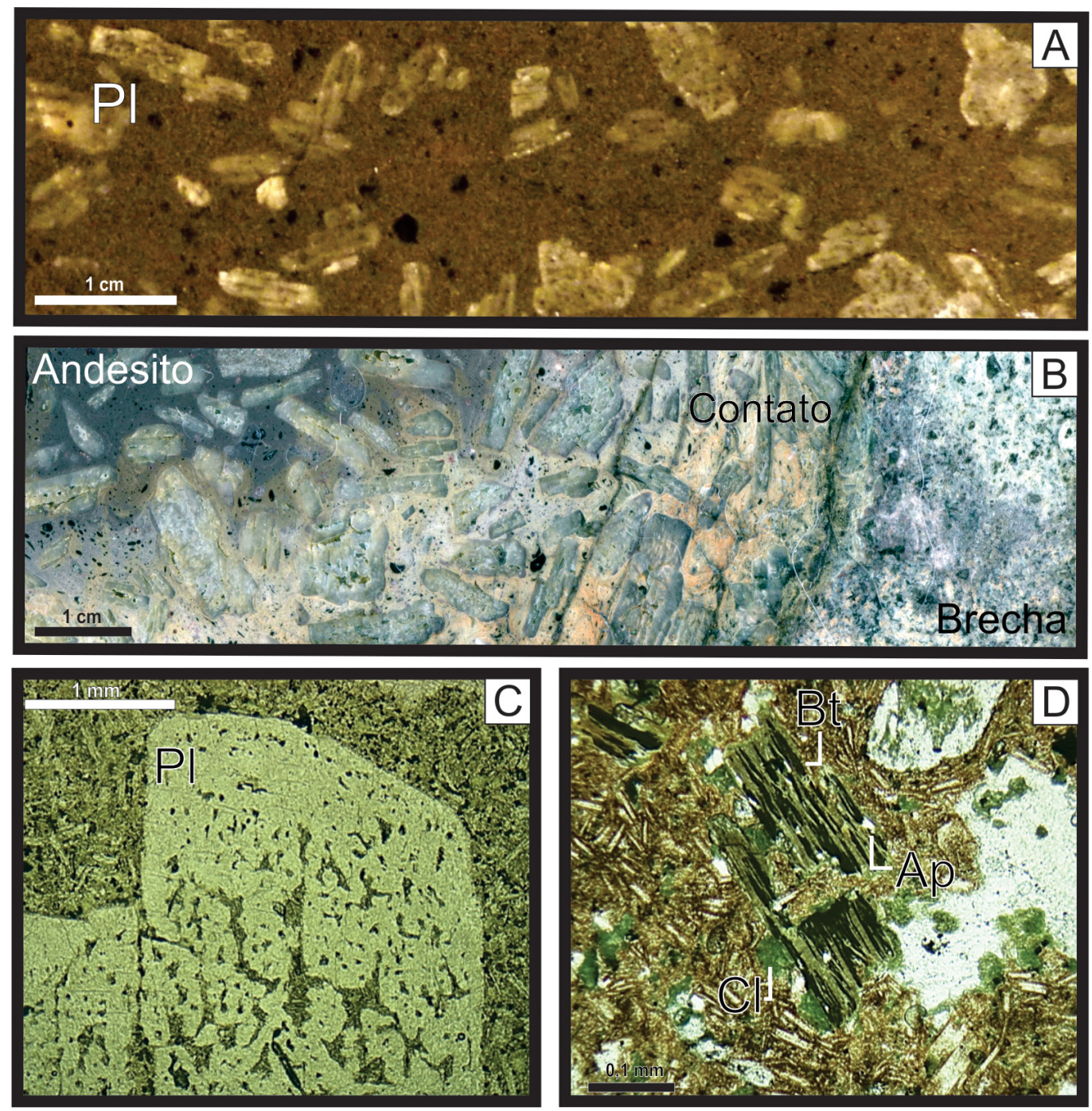

Figura 6. Fotos de amostras representativas da Sequência II na Mina do Seival. A) dique de andesito em furo de sondagem; B) contato de rocha piroclástica e dique de andesito com orientação dos plagioclásios; C) plagioclásio de dique de andesito com corrosão interna; D) dique de biotita-andesito com biotita sendo substituída para clorita e oxido de ferro, com apatitas associadas. Pl: plagioclásio; Cl: clorita; Ap: apatita.

na a formação de aglomerados de argilominerais (clorita e/ou corrensita) ou uma completa substituição dos minerais máficos. Outros argilominerais como ilita e corrensita, foram identificados por DRX de rocha total.

\subsection{Geoquímica}

As rochas piroclásticas possuem os mais altos valores de perda ao fogo (LOI) atingindo até 10\% em peso, seguido pelos andesitos amigdaloides com valores em torno de 7. Dentre os diques, o de biotita-andesito possui valores maiores, em torno de $4 \%$ em peso, enquanto os andesitos possuem valores em torno de $3 \%$ em peso. As rochas da sequência I possuem maiores valores de perda ao fogo, onde a alteração hidrotermal empobreceu a rocha em $\mathrm{SiO}_{2}$ (Fig. 7).

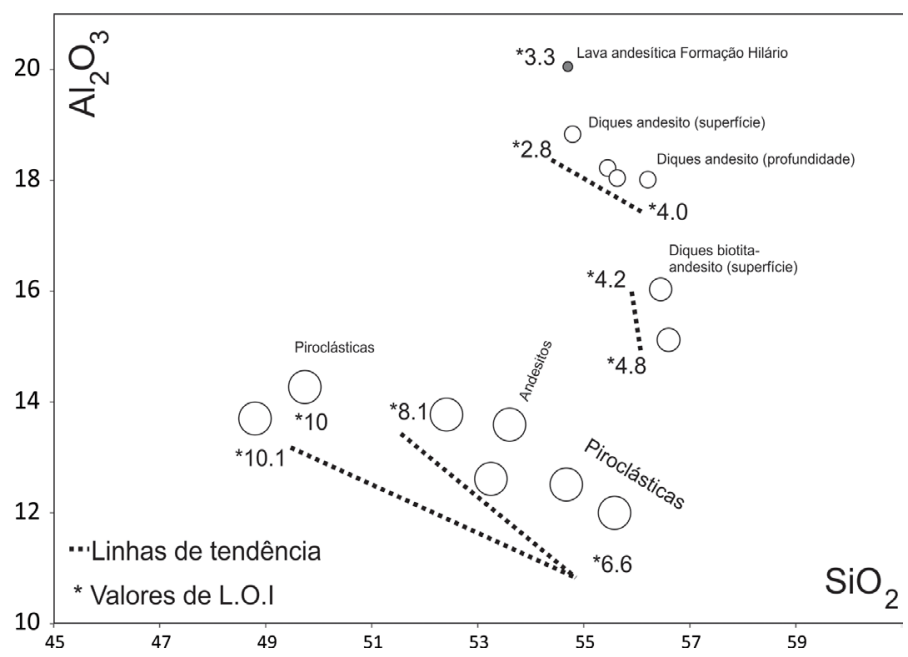

Figura 7. Diagrama $\mathrm{Al}_{2} \mathrm{O}_{3} \times \mathrm{SiO}_{2}$, com os valores de L.O.I indicados próximos às amostras. 
De acordo com a classificação no diagrama TAS (Le Maitre et al., 2002) as rochas estudadas têm composição de andesitos traqui-basálticos a traquiandesitos, com predomínio de traqui-andesito (Fig. 8). 0 efeito do hidrotermalismo, mais evidente nas amostras de rochas piroclásticas, diminui o teor de álcalis, podendo-se, portanto, concluir que o magmatismo é relacionado com as séries alcalinas saturadas em sílica. Mesmo as amostras com baixa perda ao fogo mostram ampla variação das razões $\mathrm{K}_{2} \mathrm{O} / \mathrm{Na}_{2} \mathrm{O}$, prejudicando, de modo geral, a identificação das rochas como potássicas ou sódicas. As amostras dos diques de biotita andesito, no entanto, são pouco afetadas pelo hidrotermalismo, podendo-se a partir delas reconhecer o caráter potássico ou shoshonítico $\left(\mathrm{K}_{2} \mathrm{O}>\mathrm{Na}_{2} \mathrm{O}-2\right)$ do magmatismo.

As rochas apresentam teores de sílica que variam de 48,80 a $55,58 \%$ (em peso), para as rochas piroclásticas, e de 49,74 a 62,82\% para as efusivas, e de 54,79 a $56,60 \%$ para os diques de andesito. Os teores de $\mathrm{Al}_{2} \mathrm{O}_{3}$ variam de 12,51 a $13,77 \%$ para as piroclásticas, e de 12,61 a $14,27 \%$ para as efusivas de topo, e de 15,12 a 18,83 \% para os diques de andesito. Nos diques de andesito os valores de $\mathrm{Al}_{2} \mathrm{O}_{3}$ diminuem e os de $\mathrm{SiO}_{2}$ aumentam, conforme aumenta a intensidade da alteração hidrotermal (LOI). Nos diques de biotita-andesito os teores de $\mathrm{Al}_{2} \mathrm{O}_{3}$ e $\mathrm{SiO}_{2}$ diminuem. Na sequência extrusiva, os valores mais baixos de $\mathrm{Al}_{2} \mathrm{O}_{2}$ são atribuídos à alteração hidrotermal.

O diagrama AFM (Irvine \& Baragar, 1971), ilustrando a relação entre o ferro (FeOT), o magnésio (MgO) e os álcalis $\left(\mathrm{Na}_{2} \mathrm{O}+\mathrm{K}_{2} \mathrm{O}\right)$, mostra que as rochas estudadas não são toleíticas (Fig. 9A). As rochas da sequência I possuem alta porcentagem de carbonato total (TOT/C \%) e são enriquecidas em $\mathrm{Ni}$ indicando um baixo nível de diferenciação, enquanto os diques de andesito são enriquecidos em $\mathrm{Cu}$, Ag, Au e Zn (Fig. 9B-C). O elevado teor de $\mathrm{Sr}$, e em menor grau do Ba, da maior parte das amostras, indica o caráter shoshonítico do magmatismo estudado.

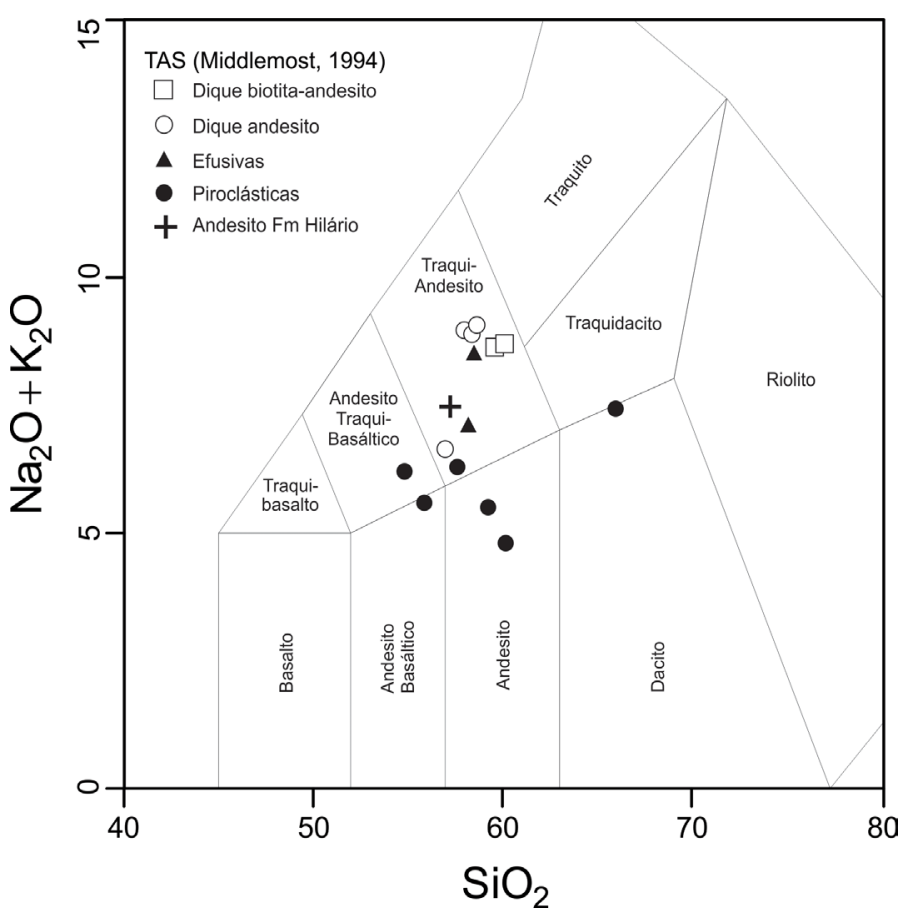

Figura 8. Classificação das sequências vulcânicas da Mina do Seival no diagrama TAS (Le Maitre et al., 2002).
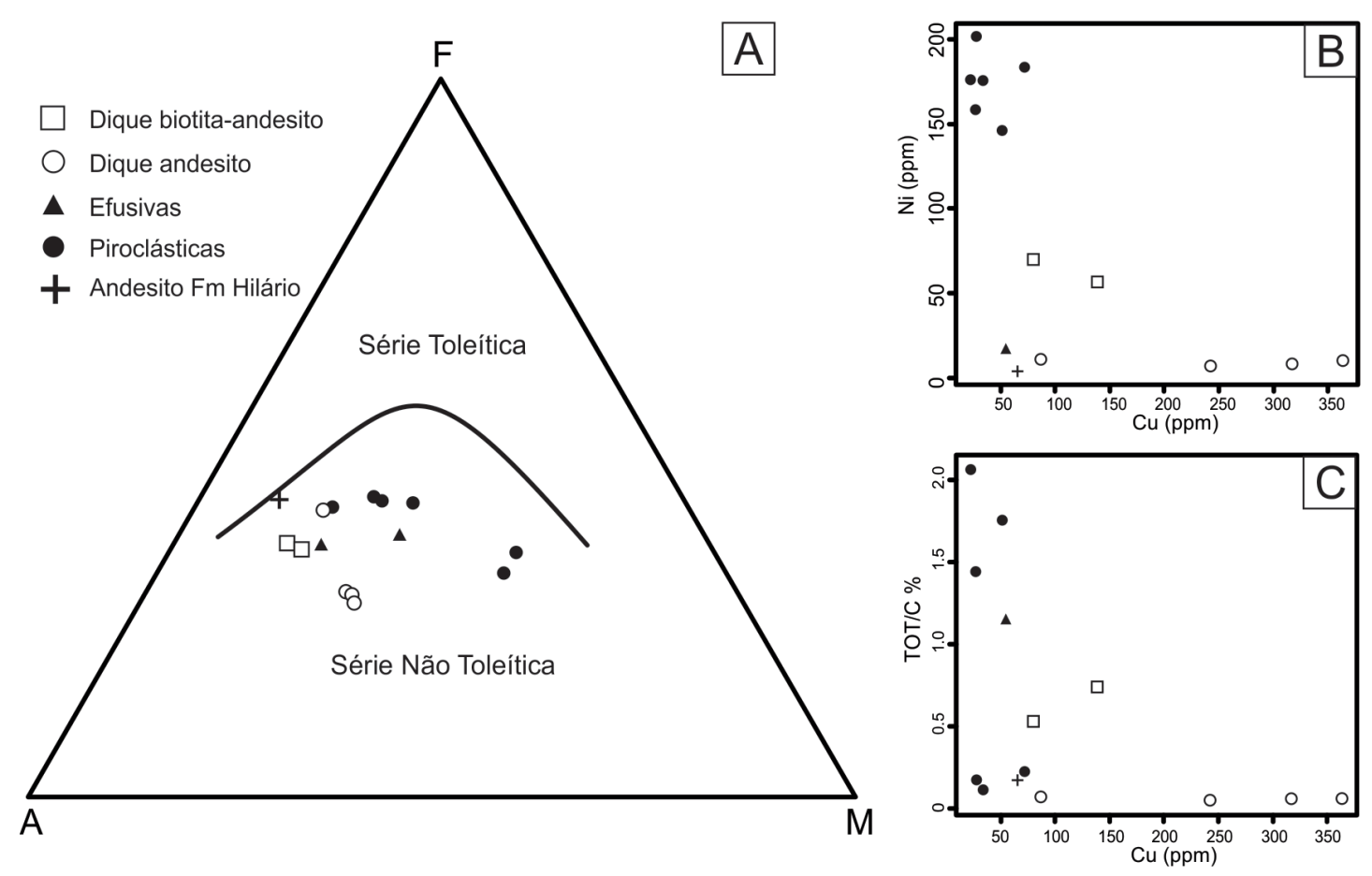

Figura 9. Diagrama AFM (Irvine \& Baragar, 1971), evidenciando o caráter não toleítico das rochas vulcânicas da Mina do Seival (A). Diagramas binários: B) Ni (ppm) x Cu (ppm); C) TOT/C \% x Cu (ppm). 
Diagramas multielementares utilizando diferentes parâmetros de normalização (E-MORB, MORB, OIB e crosta inferior) foram testados para as rochas estudadas. Destes, o que mais se aproxima dos padrões das rochas da MS é o padrão OIB (Fig. 10).

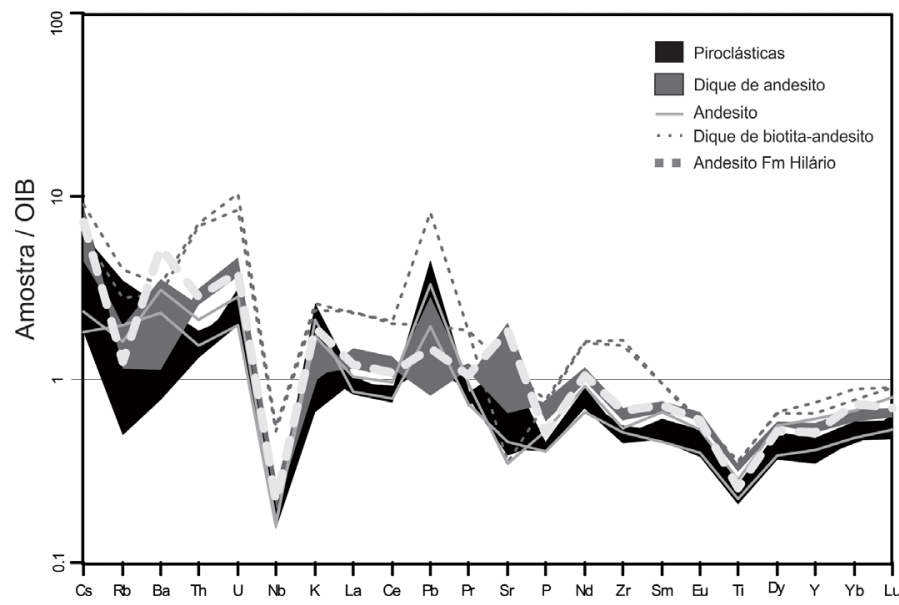

Figura 10. Diagrama multi-elementar (spiderdiagrams) normalizados pelos valores de OIB (Sun \& McDonough, 1989) para amostras representativas da sequência vulcânica Mina do Seival.

Os padrões dos elementos terras raras (ETR) das rochas das sequências I e II (Fig. 11), normalizados pelos valores condríticos de Boynton (1984) OIB (Sun \& McDonough, 1989) evidenciam que a alteração hidrotermal não mobilizou os ETR. As amostras do biotita-andesito diferem das demais por mostrarem anomalias negativas em Eu e enriquecimento em ETR leves. Os padrões ETR da sequência I são semelhantes aos padrões dos diques da sequência II, sugerindo o carácter cogenético das rochas de ambas as sequências.

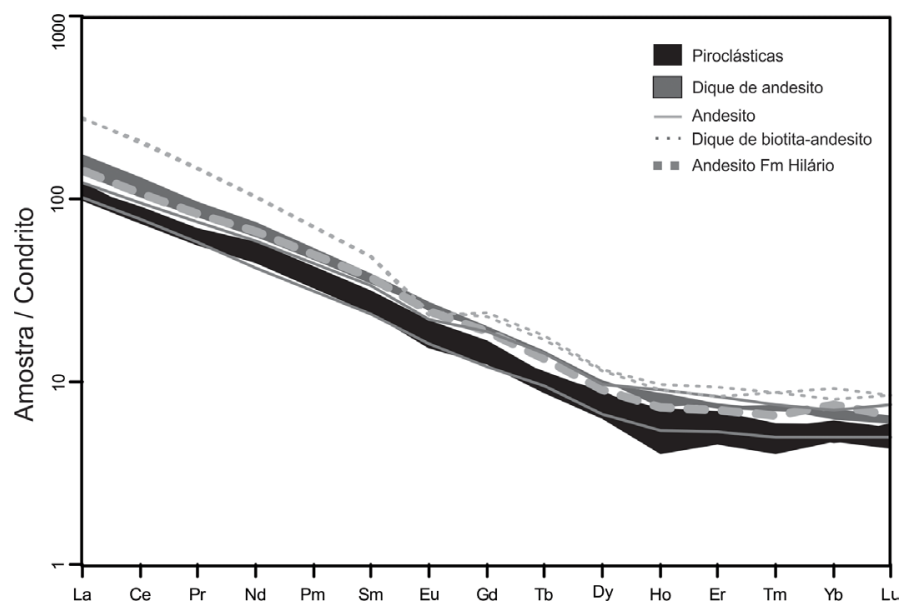

Figura 11. Diagramas multi-elementar (spiderdiagrams) para padrões de ETR normalizados pelos valores condríticos (Boynton, 1984) para amostras representativas da Mina do Seival.

A utilização de diagrama com elementos de baixa mobilidade hidrotermal, Nb/Y vs Zr/Ti (Pearce, 1996) na classificação das rochas da MS confirma o caráter alcalino saturado em sílica, ilustrado no diagrama TAS, particularmente dos diques de biotita andesito. Indica também que os magmas que deram origem a estes e as rochas extrusivas, tem composição original semelhan- te, variando de andesíticos a traquiandesíticos (Fig. 12).

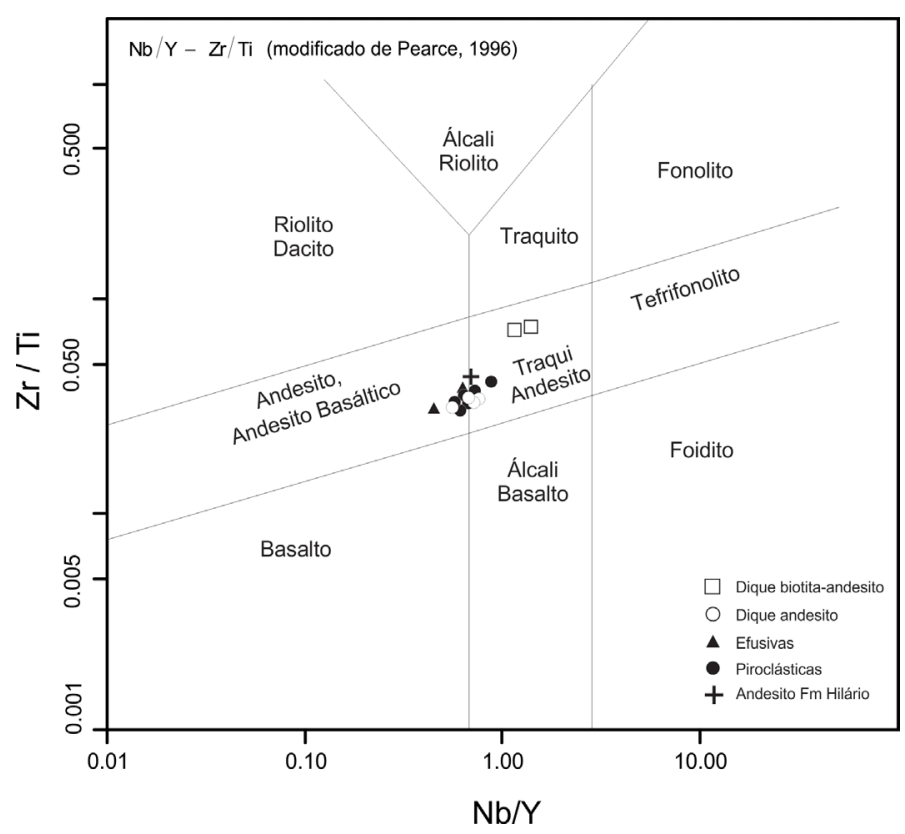

Figura 12. Diagrama de classificação geoquímica Nb/Y - Zr/Ti, de Winchester \& Floyd (1977), modificado por Pearce (1996), evidenciando mesma fonte para as sequências vulcânicas I e II da Mina do Seival.

\section{Discussão e conclusões}

As grandes variedades de litologias presentes na MS foram agrupadas em dois conjuntos independentes, sendo o primeiro constituído pelas rochas piroclásticas e efusivas, definido como Sequência I, e o segundo pelos diques de composição andesítica, Sequência II. A sequência observada em testemunhos mostra rochas piroclásticas, com tamanho predominante lapili, sobrepostas por andesitos amigdaloides. Os diques de andesito da Sequência II ocorrem preferencialmente com direção NE e possuem variação mineralógica e geoquímica, de andesitos, biotita-andesitos e lamprófiros espessartíticos.

A presença de rochas lamprofíricas entre as encaixantes da Mina do Seival sugere que estes magmas podem ter papel relevante na formação das mineralizações associadas ao magmatismo da BC, conforme sugerido por Müller et al. (2012).

A alteração hidrotermal foi dividida em três episódios. A primeira fase da alteração hidrotermal é representada pela esmectita, que possivelmente está relacionada a processos residuais magmáticos na forma fibrosa e cristalina. Está associada com cristobalita, ocorrendo nos interstícios dos grãos, dentro de clastos vulcânicos da brecha. Por vezes, ocorre alterando o material vítreo. Provavelmente trata-se de uma alteração argílica intermediária. A segunda fase é caracterizada pela assembleia mineralógica clorita + epidoto (pistacita) + carbonato (calcita) + sulfeto (pirita e calcosina) + barita + quartzo + hematita. Essa alteração ocorre tanto pervasiva, num evento de maior temperatura, 
quanto venular, representada pelos veios de carbonato, clorita e quartzo. A alteração nos níveis mais rasos é pervasiva com a total substituição do anfibólio por clorita e carbonato. A terceira fase ocorre nos diques e é caracterizada como propilitização (clorita + epidoto + sulfeto), e sericitização dos feldspatos. Esse evento é de alta temperatura hidrotermal $\left(200-300^{\circ} \mathrm{C}\right)$ indicado pela abundância de epidoto.

Os processos de carbonatação, cloritização e hematitização, estão associados às amostras mais superficiais, acima dos $30 \mathrm{~m}$ de profundidade, e ocorrem próximos aos depósitos, ocorrências e diques de andesito.

A alteração hidrotermal presente com diferentes intensidades na maior parte das rochas encaixantes da Mina do Seival dificulta o reconhecimento de padrões composicionais, tanto para elementos maiores como traços, que permitam relacioná-las com as séries magmáticas.

A utilização de elementos com baixa mobilidade e a valorização das amostras com menos evidências petrográficas de hidrotermalismo, indicam que os magmas parentais das sequências I e II eram alcalinos saturados em sílica, potássicos ou shoshoníticos. Os padrões muito regulares de ETR e os teores elevados de $\mathrm{Sr}$ e Ba, apesar da grande variação, apontam também para a afinidade shoshonítica.

Os biotita traquiandesitos destacam-se das demais rochas da ASLS por seus teores mais elevados de $\mathrm{Nb}, \mathrm{Zr}$, ETRP, U e Th, o que é consistente com seu caráter mais jovem e sugere que suas fontes possuem características intraplaca mais acentuadas.

As relações entre os elementos de baixa mobilidade sugerem que todo conjunto de rochas encaixantes da MS é cogenético, enquanto os padrões de elementos traços que se aproximam dos OIB, indicam que as fontes do magmatismo presente na MS foram afetadas por uma subducção prévia (Condie, 2005). Este conjunto de características petrográficas e geoquímicas, bem como as relações estratigráficas, indicam que as encaixantes da MS podem ser incluídas na Associação Shoshonítica de Lavras do Sul, conforme discutido em Lima \& Nardi (1998), Sommer et al. (2006) e Liz et al. (2009a).

Nos diques alterados hidrotermalmente (perda ao fogo $<5$ ) os teores de elementos incompatíveis, $\mathrm{Rb}$, $\mathrm{Ba}$ e $\mathrm{Pb}$, são elevados em relação as piroclásticas (perda ao fogo < 10) que apresentam uma redução destes valores. Já o Ti, $\mathrm{Al}, \mathrm{Hf}$, Ta e U comportam-se como elementos imóveis em ambas as litologias. Os teores mais elevados de $\mathrm{Cu}$, $\mathrm{Zn}$ e Ni nos diques andesíticos, mesmo quando comparados às rochas hidrotermalisadas, sugerem que as principais ocorrências de mineralização de Cu da MS têm origem magmática.

Os dados químicos de rocha total indicam que o enriquecimento dos elementos componentes da mineralização $(\mathrm{Ag}, \mathrm{Au}, \mathrm{Cu}$ e $\mathrm{Zn}$ ) estão relacionados à Sequência II. Os teores de $\mathrm{Au}$ e $\mathrm{Cu}$ são mais elevados nas amostras com menores concentrações de carbonatos, sugerindo que a carbonatação não tem relação com a distribuição destes elementos nas rochas estudadas.

Agradecimentos - Somos gratos aos editores e às revisoras - profs. Delia del Pilar Montecinos de Almeida e Ignez Guimarães - pelas correções, críticas e sugestões. Ao CNPq pelo auxilio do projeto de pesquisa (CNPq: 485995/2011-5) e bolsa de mestrado (bolsa de mestrado processo no $558550 / 2010$ 0 ); ao PPGGEO e ao IGEO-UFRG pela infraestrutura e logística; à Votarantim Metais pelas amostragens; a Luiz Delfino Albarnaz e UNIPAMPA pela infraestrutura nos trabalhos de campo.

\section{Referências}

Almeida, E.F.M. \& Hasui, Y. 1984. O Pré-Cambriano do Brasil. São Paulo, Blücher, 378p.

Bongiolo, E.M., Renac, C., Mexias, A.S., Gomes, M.E.B., Ronchid, L.H. \& Patrier-Mase, P. 2011. Evidence of Ediacaran glaciation in southernmost Brazil through magmatic to meteoric fluid circulation in the porphyry-epithermal $\mathrm{Au}-\mathrm{Cu}$ deposits of Lavras do Sul. Precambrian Research, 189: 404- 419.

Boynton, W.V. 1984. Geochemistry of the Rare Earth Elements: meteorite studies. In Henderson P. (ed), Rare Earth Element Geochemistry, Elsevier, Amsterdam, p. 63114.

Chemale Jr., F. 2000. Evolução Geológica do Escudo Sul-rio-grandense. In Holz, M.; De Ros, L. F. Geologia do Rio Grande do Sul. Porto Alegre: Ed. da Universidade/UFRGS, p. 13-52.

Condie, K. 2005. TTGs and adakites: are they both slab melts? Lithos, 80: 33-44.

Fisher, R. V. 1966 . Rocks composed of volcanic fragments and their classification. Earth-Sciences Reviews, 1: 287298.

Gastal, M.C., Martil, M.M.D., Bitencourt, M.F.S. \& Tomasi, L.C. 2008. Remanescentes de uma Estrutura de Subsidência de Caldeira Neoproterozóica, Lavras do Sul, RS: Parte 2. Petrografia e Mineralogia do Monzodiorito Arroio do Jacques. SIMPÓSIO DE VULCANISMO E AMBIENTES ASSOCIADOS, 4, 2008, Foz do Iguaçu, 6p.

Irvine, T.N., Baragar A.W. R. A. 1971. A guide to the chemical classification of the common volcanic rocks. Canadian Journal of Earth Sciences, 8: 523-548.

Janikian, L., Almeida, R.P., Fragoso-Cesar, A.R.S. \& Fambrini, G.L. 2003. Redefinição do Grupo Bom Jardim (Neoproterozóico III) em sua área-tipo: litoestratigrafia, evolução paleoambiental e contexto tectônico. Revista Brasileira de Geociências, 33: 349-362.

Janikian, L., Almeida, R.P., Trindade, R.I.F., Fragoso-Cesar, A.R.S., D’Agrella-Filho, M.S., Dantas, E.L. \& Tohver, E. 2008. The continental record of Ediacaran volcano-sedimentary successions in southern Brazil and their global implications. Terra Nova. 20: 259-266.

Le Maitre, R.W., A. Streckeisen, B. Zanettin, M.J. Le Bas, B. Bonin, P. Bateman, G. Bellieni, A. Dudek, S. Efremova, J. Keller, J. Lamiere, P.A. Sabine, R. Schmid, H. Sorensen \& A.R. Wooley. 2002. Igneous Rocks: IUGS Classification and glossary: recommendations of the International Union of Geological Sciences, Subcommission on the Systematics of Igneous Rocks ( $2^{a}$ ed). Cambridge, Cambridge University Press, 236p.

Lima, E.F. 1985. Petroquímica e Prospecção Litogeoquímica 
da Área da Merita, Região de Volta Grande, Lavras do Sul, RS. Porto Alegre. 187p. Dissertação de Mestrado em Geociências, Instituto de Geociências, Universidade Federal do Rio Grande do Sul.

Lima, E.F. 1995. Petrologia das Rochas Vulcânicas e Hipabissais da Associação Shoshonítica de Lavras do Sul - ASLS, $R S$. Porto Alegre, 338p. Tese de Doutorado, Programa de Pós-graduação em Geociências, Instituto de Geociências, Universidade Federal do Rio Grande do Sul.

Lima, E.F. \& Nardi, L.V.S. 1998. The Lavras do Sul Shoshonitic Association: implications for the origin and evolution of Neoproterozoic shoshonitic magmatism southernmost Brazil. Journal of South American Earth Science, 11(1): 67-77.

Lima, E.F.L., Sommer, C.A. \& Nardi, L.V.S. 2007. O vulcanismo Neoproterozóico-Ordoviciano no escudo sul-riograndense: os ciclos vulcânicos da Bacia do Camaquâ. In: Iannuzzi, R.; Frantz, J. C. (Eds). 50 anos de Geologia: Instituto de Geociências. Contribuições. Porto Alegre: Comunicação e Identidade, p. 79-97.

Liz, J.D., Lima, E.F. \& Nardi, L.V.S. 2009 a. Avaliação de fontes magmáticas de séries shoshoníticas pós-colisionais com base na normalização pela Associação Shoshonítica de Lavras do Sul - aplicação de Sliding Normalization. Revista Brasileira de Geociências, 39 (1): 55-66.

Liz, J.D., Lima, E.F., Nardi L.V.S., Sommer, C.A., Saldanha D.L. \& Pierosan, R. 2009 b. Caracterização Geológica e Petrologia das Rochas Monzoníticas da Associação Shoshonítica de Lavras do Sul (RS). Revista Brasileira de Geociências, 39 (2): 244-255.

Lopes, R.W. 2011. Alteração hidrotermal e mineralizações de cobre na Mina do Seival, Bacia do Camaquã, RS. 90p. Monografia de Conclusão de Curso, Curso de Geologia, Instituto de Geociências, Universidade Federal do Rio Grande do Sul.

Matté, V., Sommer, C.A., Lima, E. F., Saldanha, D.L., Pinheiro-Sommer, J.A. \& Liz, J.D. 2012. Rochas dioríticas do Platô da Ramada, Rio Grande do Sul, e sua relação com o vulcanismo alcalino da Formação Acampamento Velho, Neoproterozoico do Escudo Sul-Rio-Grandense. Revista Brasileira de Geociências, 42 (2): 343-36.

Mexias, A.S., Bongiolo, E.M., Gomes, M.E.B., Formoso, M.L.L. \& Frantz, J.C. 2007. Alterações hidrotermais e mineralizações nas rochas da Associação Plutono-Vulcano-Sedimentar da região de Lavras do Sul-RS. In: Ianuzzi, R., Frantz, J.C. (eds.). 50 Anos de Geologia: Instituto de Geologia. Contribuições. Porto Alegre, Ed. Comunicação e Identidade, p. 143-159.

Middlemost, E.A.K. 1994. Naming materials in the magma/ igeous rock system. Earth Science Review, 37: 215-224.

Müller, I.F., Nardi, L.V.S., Lima, E.F. \& Mexias, A.S. 2012. Os diques latíticos portadores de ouro e sulfetos da Associação Shoshonítica de Lavras do Sul - RS: Petrogênese e Geoquímica. Revista Pesquisas em Geociências, 39 (2):
173-191.

Nardi, L.V.S. 1984. Geochemistry and petrology of the Lavras Granite Complex, RS, Brazil. London, 268p. PhD Thesis, London University.

Nardi, L.V.S. \& Bitencourt, M.F. 2007. Magmatismo Granítico e Evolução Crustal no Sul do Brasil. In: Iannuzzi, R.; Frantz, J. C. (Eds). 50 anos de Geologia: Instituto de Geociências. Contribuições. Porto Alegre, Ed. Comunicação e Identidade, p. 125-141.

Nardi, V.S.N. \& Lima, E.F. 1985. A Associação Shoshonítica de Lavras do Sul, RS. Revista Brasileira de Geociências, 15: 139-146.

Paim, P.S.G., Chemale Jr., F. \& Lopes, R. C. 2000. A Bacia do Camaquã. In HOLZ, M.; DE ROS, L. F. (Ed.). Geologia do Rio Grande do Sul. Porto Alegre: Ed. da Universidade/UFRGS, p. 231-374.

Pearce, J. 1996. Sources and settings of granitic rocks. Episodes, 19(4): 120-125.

Reischl, J.L. 1978. Mineralizações cupriferas associadas a vulcânicas na Mina do Seival. In: XXX CONGRESSO BRASILEIRO DE GEOLOGIA, 30. 1978, Recife. Anais... Recife, SBG. v 4, p. 1568-1582.

Remus, M.V.D, Hartmann, L.A., McNaughton, N.J., Groves,D.I. \& Reischl, J.L. 2000. Distal Magmatic-hydrothermal origin for the Camaquã $\mathrm{Cu}(\mathrm{Au}-\mathrm{Ag})$ and Santa Maria $\mathrm{Pb}, \mathrm{Zn}$ (Cu-Ag) deposits, Southern Brazil. Gondwana Research, 3: 155-174.

Ribeiro, M. \& Fantinel, L.M. 1978. Associacões petrotectônicas do Escudo Sul-Riograndense: I Tabulação e distribuicão das associações petrotectônicas do Escudo do Rio Grande do Sul. Inheringia Serviço Geológico, 5: 19-54.

Sommer, C.A., Lima, E.F., Nardi, L.V.S., Liz, J.D. \& Waichel, B.L. 2006. The evolution of Neoproterozoic magmatism in southernmost Brazil: shoshonitic, high-K tholeiitic and silica-saturated, sodic, alkaline volcanism in post-collisional basins. Anais da Academia Brasileira de Ciências, 78(3): 573-589.

Sun, S.S. \& Mcdonough, W.F. 1989. Chemical and isotopic systematics of oceanic basalts: implications for mantle composition and processes. In: SOUNDERS, A.D.; NORRY, M.J. (editors). Magmatism in the ocean basins. Geological Society London, special publication, 42: 313-345.

Wildner, W., Ramgrab, G.E., Lopes, R.C. \& Iglesias, C.M.F. 2008. Mapa Geológico do Rio Grande do Sul. Porto Alegre: CPRM, 2008, 1 mapa. Escala 1:750.000. 1 CD-ROM.

Wildner, W., Nardi, .L.V.S. \& Lima, E.F. 1999. Post-Collisional Alkaline Magmatism on the Taquarembó Plateau: A Well Preserved Neoproterozoic-Cambrian Plutono-Volcanic Association In Southern Brazil. International Geology Review, 41(12): 1082-1098.

Winchester, J.A. \& Floyd, P.A. 1977. Geochemical discrimination of different magma series and theiur differentiation products using immobile elements. Chemical Geology, 20: 325-343.

Manuscrito 517.

Editores: Maria de Fátima Bitencourt. 